\title{
Penerapan Data Mining Untuk Mengestimasi Laju Pertumbuhan Penduduk Menggunakan Metode Regresi Linier Berganda Pada BPS Deli Serdang
}

\author{
Purwadi, Puji Sari Ramadhan, Nurdiyanti Safitri \\ STMIK Triguna Dharma
}

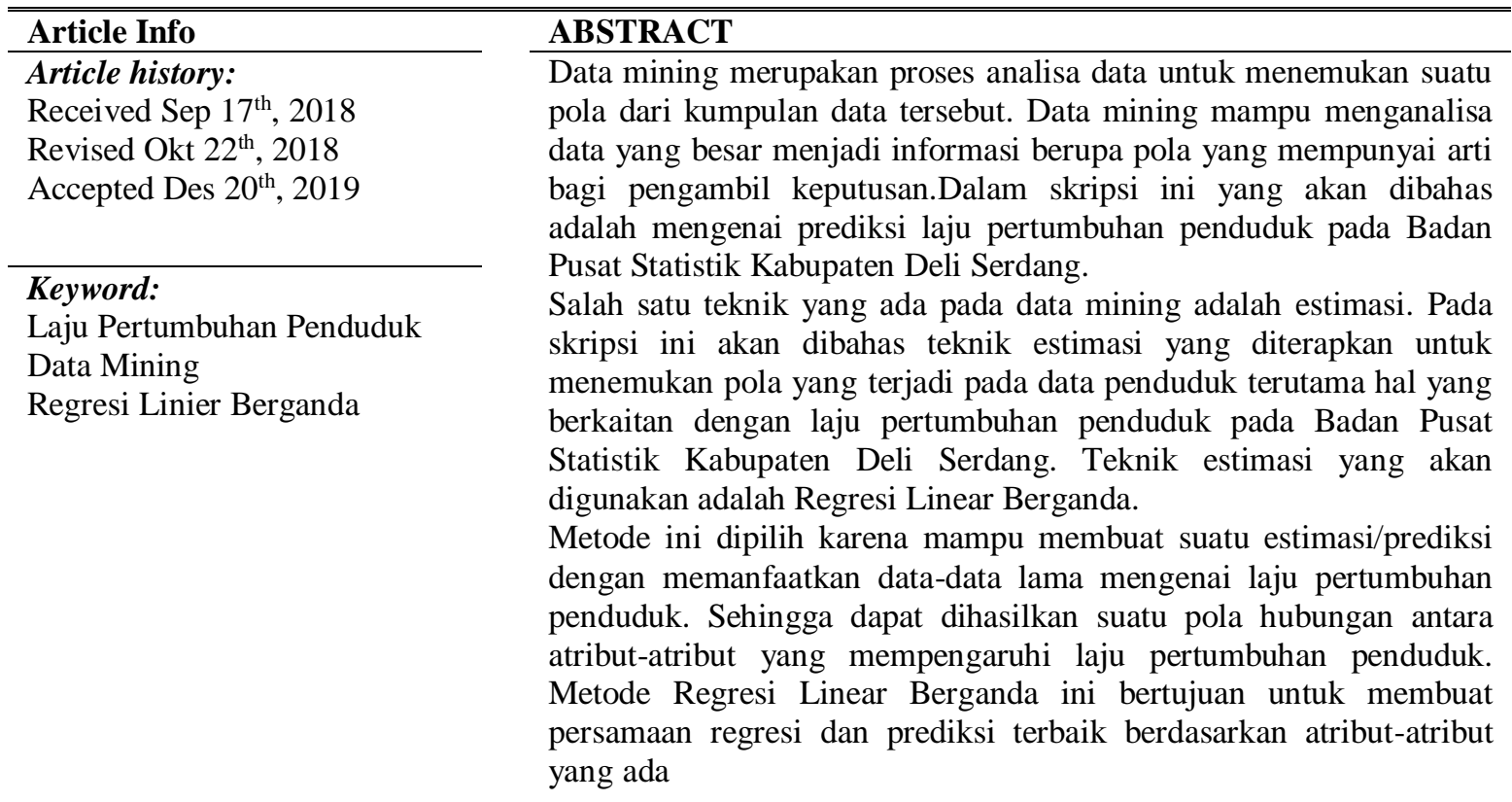

Copyright (c) 2019 STMIK Triguna Dharma. All rights reserved.

\section{PENDAHULUAN}

Badan Pusat Statistik (BPS) adalah lembaga pemerintah nonkementrian yang bertanggung jawab langsung kepada presiden. Salah satu lembaga BPS yang ada di Sumatera Utara adalah BPS Deli Serdang. Termasuk salah satu tugas dan fungsi BPS adalah melakukan pendataan statistik terhadap jumlah penduduk. Adapun pendataan penduduk rutin oleh dilakukan BPS Deli Serdang setiap beberapa tahun sekali. Namun BPS Deli Serdang mengalami kesulitan dalam mengestimasi laju pertumbuhan penduduk setiap tahunnya dikarenakan beberapa kendala. Dari beberapa karya ilmiah ternyata ada suatu cara untuk dapat mengestimasi laju pertumbuhan penduduk yaitu dengan menggunakan teknik Data Mining.

Data Mining merupakan penambangan atau penemuan informasi baru dengan mencari pola atau aturan tertentu dari sejumlah data dalam jumlah besar yang diharapkan dapat mengatasi kondisi tersebut. Data Mining sendiri memiliki beberapa metode diantaranya adalah metode regresi linear berganda. Kemudian metode regresi linear berganda akan digunakan untuk membangun suatu aplikasi perangkat lunak yang berbasis desktop programming. Yang diharapkan dapat membantu memecahkan masalah dalam mengestimasi laju pertumbuhan penduduk.

\section{LANDASAN TEORI}

\subsection{Laju Pertumbuhan Penduduk}

Pertumbuhan penduduk adalah perubahan populasi sewaktu-waktu, dan dapat dihitung sebagai perubahan dalam jumlah individu dalam sebuah populasi menggunakan "per waktu unit" untuk pengukuran. Sebutan pertumbuhan penduduk merujuk pada semua spesies, tapi selalu mengarah pada manusia, dan sering digunakan secara informal untuk sebutan demografi nilai pertumbuhan penduduk, dan digunakan untuk merujuk pada pertumbuhan penduduk dunia. Pengertian lainnya adalah perubahan jumlah penduduk di suatu 
wilayah tertentu setiap tahunnya. Kegunaannya adalah memprediksi jumlah penduduk suatu wilayah di masa yang akan datang.

Laju pertumbuhan penduduk adalah angka yang menunjukan tingkat pertambahan penduduk pertahun dalam jangka waktu tertentu. Angka ini dinyatakan sebagai persentase dari penduduk dasar. Laju pertumbuhan penduduk dapat dihitung menggunakan tiga metode, yaitu aritmatik, geometrik dan eksponesial (https://sirusa.bps.go.id/index.php).

Dalam demografi dan ekologi, nilai pertumbuhan penduduk (NPP) adalah nilai kecil dimana jumlah individu dalam sebuah populasi meningkat. NPP hanya merujuk pada perubahan populasi pada periode waktu unit, sering diartikan sebagai persentase jumlah individu dalam populasi ketika dimulainya periode.

\subsection{Data Mining}

Data Mining adalah suatu istilah yang digunakan untuk menemukan pengetahuan yang tersembunyi di dalam database. Data Mining merupakan proses semi otomatic yang menggunakan teknik statistik, matematika, kecerdasan buatan, dan machine learning untuk mengekstraksi dan mengidentifikasi informasi pengetahuan yang berguna dan bermanfaat yang tersimpan di dalam database besar. Data Mining (DM) adalah serangkaian proses untuk menggali nilai tambah dari suatu kumpulan data berupa pengetahuan yang selama ini tidak diketahui secara manual. Patut diingat bahwa kata mining sendiri berarti usaha untuk mendapatkan sedikit barang berharga dari sejumlah besar material dasar. Karena itu Data Mining sebenarnya memiliki akar yang panjang dari bidang ilmu seperti kecerdasan buatan (artificial intelligent), machine learning, statistik dan database. Data Mining adalah analisis otomatis dari data yang berjumlah besar atau kompleks dengan tujuan untuk menemukan pola atau kecenderungan yang penting yang biasanya tidak disadari keberadaannya (Pramudiono, 2006:42).

Alasan utama untuk menggunakan data mining adalah untuk membantu dalam analisis koleksi pengamatan perilaku. Data tersebut rentan terhadap collinearity karena diketahui keterkaitan. Fakta yang tak terelakkan data mining adalah bahwa subset/set data yang dianalisis mungkin tidak mewakili seluruh domain, dan karenanya tidak boleh berisi contoh-contoh hubungan kritis tertentu dan perilaku yang ada di bagian lain dari domain. Untuk mengatasi masalah semacam ini, analisis dapat ditambah menggunakan berbasis percobaan dan pendekatan lain, seperti Choice Modelling untuk data yang dihasilkan manusia. Dalam situasi ini, yang melekat dapat berupa korelasi dikontrol untuk, atau dihapus sama sekali, selama konstruksi desain eksperimental.Beberapa teknik yang sering disebut-sebut dalam literatur Data Mining dalam penerapannya antara lain: clustering, classification, association rule mining, neural network, genetic algorithm dan lain-lain. Yang membedakan persepsi terhadap Data Mining adalah perkembangan teknik-teknik Data Mining untuk aplikasi pada database skala besar. Sebelum populernya Data Mining, teknik-teknik tersebut hanya dapat dipakai untuk data skala kecil saj

\subsection{Metode Regresi Linear}

Regresi linear merupakan satu cara prediksi yang menggunakan garis lurus unutk menggambarkan hubungan diantara dua variabel atau lebih. Variabel adalah besaran yang berubah-ubah nilainya. Selanjutnya variabel tersebut terbagi atas dua jenis yaitu variabel pemberi pengaruh dan variabel terpengaruh. Variabel pemberi pangaruh dapat dianalogikan sebab, sementara variabel terpengaruh merupakan akibat (Sani Susanto, 2010 : 33).

Informasi yang dihasilkan dari data mining dengan metode Regresi Linear ini sendiri juga bisa dijadikan sebagai dasar untuk pengambilan keputusan. Contoh kasus metode data mining ini biasanya dipakai dalam data perhitungan sebuah waktu yang dibutuhkan seseorang untuk mengantar pizza kepada konsumennya, yang nantinya akan menunjukkan jarak yang akan ditempuh oleh pengantar pizza itu, jumlah pesanan yang dipesan oleh konsumen dan juga banyaknya lampu lalulintas yang akan dilewatinya.

Algoritma Regresi Linear termasuk jenis aturan classification and regression pada data mining, selain Regresi Linear yang termasuk pada golongan ini adalah Support Vector Machine, Logistic Regression dan lain-lain. Analisis Regresi Linear adalah teknik data mining untuk menentukan bahwa terdapat hubungan antara variable yang ingin diramalkan (variabel tak bebas) dengan variabel lain (variabel bebas). Selanjutnya peramalan ini didasarkan pada asumsi bahwa pola pertumbuhan data historis yang bersifat linier, walaupun sebenarnya tidak $100 \%$ linier. Pola pertumbuhan ini didekati dengan suatu model yang menggambarkan hubungan-hubungan yang terkait dalam suatu keadaan.

\section{PEMBAHASAN DAN HASIL}

Kehadiran data mining dilatarbelakangi dengan masalah data explosion yang dialami akhir-akhir ini dimana banyak perusahaan/bank/organisasi telah mengumpulkan data sekian tahun lamanya (data pembelian, data penjualan, data nasabah, data transaksi, dan lain-lain). Seperti yang terjadi pada sebuah perusahaan asuransi, data yang tersimpan selama ini hanya sebagai dokumentasi dan hanya dipakai untuk kebutuhan transaksi saja. Pertanyaannya sekarang, apakah data tersebut akan dibiarkan menggunung, tidak berguna lalu dibuang, 
ataukah kita dapat me-“nambang”-nya untuk mencari 'emas' dan 'berlian' yaitu informasi yang berguna untuk organisasi kita.

Sama halnya dengan BPS Kabupaten Deli Serdang yang telah beroperasi puluhan tahun, sehingga banyak sekali data-data yang sebenarnya dapat digali untuk keperluan informasi yang lebih baik. Sehingga permasalahasan data ini dimanfaatkan untuk mengestimasi pertumbuhan penduduk, dengan menimbang atribut-atribut yang telah ada pada database yang ada pada Badan Pusat Statistik (BPS) Kabupaten Deli Serdang.

Untuk itu penerapan metode regresi linear berganda merupakan metode yang paling cocok untuk mencapai tujuan tersebut. Regresi linear berganda merupakan metode data mining yang telah populer di dunia pendidikan yang berguna untuk membuat estimasi atau prediksi di masa yang akan datang.

Ada beberapa tahapan dalam membuat penyelesaian masalah dengan metode regresi linear berganda dalam yaitu :

1. Mempersiapkan data training. Data training biasanya diambil dari data histori yang pernah terjadi sebelumnya atau disebut data masa lalu dan sudah dikelompokkan dalam kelas-kelas tertentu.

2. Menentukan variabel bebas dan variabel tidak bebas.

Variabel bebas yaitu :

Jumlah Laki-Laki (X1)

Jumlah Perempuan (X2)

Variabel tidak bebas yaitu :

Jumlah Penduduk (Y)

3. Mencari nilai persamaan regresi linear berganda

$\mathrm{Y}=\mathrm{a}+\mathrm{b} 1 . \mathrm{x} 1+\mathrm{b} 2 . \mathrm{x} 2$

4. Menentukan nilai konstanta dan koefisien regresi.

Dalam kasus ini akan diambil dari database yang ada pada BPS Kabupaten Deli Serdang selama tahun 2010-2017. Data tersebut akan digunakan dalam perhitungan metode regresi linear berganda untuk menganalisa mengenai mengestimasi pertumbuhan penduduk. Data penduduk tersebut selanjutnya akan dilakukan pra-proses untuk menghasilkan data khusus yang siap untuk dibentuk menjadi sebuah informasi baru.

Tabel.1 Database Penduduk Kabupaten Deli Serdang

\begin{tabular}{|c|c|c|c|c|c|c|}
\hline No & Kecamatan & 2010 & 2012 & 2015 & 2016 & 2017 \\
\hline 1 & Gunung Meriah & 2.742 & 2.801 & 2.874 & 2.949 & 3.087 \\
\hline 2 & STM Hulu & 12.333 & 13.010 & 14.023 & 14.327 & 15.021 \\
\hline 3 & Sibolangit & 19.654 & 21.471 & 22.476 & 23.008 & 24.102 \\
\hline 4 & Kutalimbaru & 35.870 & 38.351 & 40.656 & 41.549 & 42.141 \\
\hline 5 & Pancur Batu & 84.919 & 91.212 & 96.288 & 98.367 & 99.225 \\
\hline 6 & Namo rambe & 36.651 & 38.421 & 41.479 & 42.436 & 43.233 \\
\hline 7 & Biru-Biru & 34.020 & 36.643 & 38.646 & 39.498 & 40.395 \\
\hline 8 & STM Hilir & 30.363 & 31.445 & 34.777 & 35.553 & 36.555 \\
\hline 9 & Bangun Purba & 21.550 & 22.352 & 24.354 & 25.086 & 26.081 \\
\hline 10 & Galang & 61.508 & 66.061 & 69.964 & 71.520 & 72.321 \\
\hline 11 & Tjg. Morawa & 192.759 & 207.041 & 218.084 & 222.634 & 225.232 \\
\hline 12 & Patumbak & 88.961 & 94.256 & 100.243 & 102.470 & 104.173 \\
\hline 13 & Deli Tua & 60.624 & 65.076 & 68.658 & 70.097 & 71.156 \\
\hline 14 & Sunggal & 244.187 & 258.101 & 276.263 & 282.009 & 291.022 \\
\hline 15 & H. Perak & 150.054 & 163.223 & 170.065 & 173.708 & 175.503 \\
\hline 16 & Labuhan Deli & 60.190 & 65.254 & 68.218 & 69.655 & 70.622 \\
\hline 17 & PS. Tuan & 384.672 & 404.350 & 436.003 & 445.223 & 450.220 \\
\hline 18 & Batang Kuis & 56.270 & 62.743 & 63.743 & 65.090 & 65.090 \\
\hline
\end{tabular}




\begin{tabular}{|c|c|c|c|c|c|c|}
\hline 19 & Pantai Labu & 43.135 & 46.992 & 48.893 & 49.938 & 50.731 \\
\hline 20 & Beringin & 52.415 & 55.432 & 59.537 & 60.840 & 61.240 \\
\hline 21 & Lubuk Pakam & 80.847 & 88.456 & 91.981 & 94.033 & 95.253 \\
\hline 22 & Pagar merbau & 36.777 & 37.741 & 41.723 & 42.621 & 43.420 \\
\hline \multicolumn{2}{|r|}{ Total : } & 1.790 .431 & 1.897.290 & 2.029.203 & 2.072.521 & 2.105 .476 \\
\hline
\end{tabular}

Tabel.2 Akumulasi Data Penduduk Per Tahun Berdasarkan Jenis Kelamin

\begin{tabular}{|c|c|c|c|}
\hline \multirow{2}{*}{ Tahun } & \multicolumn{2}{|c|}{ Penduduk } & \multirow{2}{*}{ Jumlah Penduduk } \\
\cline { 2 - 4 } & Laki-Laki & Perempuan & Y \\
\cline { 2 - 4 } & $\mathbf{X 1}$ & $\mathbf{X 2}$ & 1.790 .431 \\
\hline 2010 & 989.201 & 801.200 & 1.897 .290 \\
\hline 2012 & 1.002 .145 & 895145 & 2.029 .308 \\
\hline 2015 & 1.021 .188 & 1.008 .120 & 2.072 .421 \\
\hline 2016 & 1.043 .114 & 1.029 .407 & 2.105 .476 \\
\hline 2017 & 1.058 .234 & 1.047 .242 & 9.894 .926 \\
\hline Jumlah & 5.113 .882 & 4.781 .114 & \\
\hline
\end{tabular}

Dikarenakan dalam perhitungan regresi linear berganda banyak dilakukan perkalian dan perpangkatan maka untuk menyederhanakan bilangan akan dibagi 1000. Sehingga menghasilkan tabel dibawah ini.

Tabel.3 Penyederhanaan Data Penduduk (dibagi 1000)

\begin{tabular}{|c|c|c|c|}
\hline \multirow{2}{*}{ Tahun } & \multicolumn{2}{|c|}{ Penduduk } & \multirow{2}{*}{ Jumlah Penduduk } \\
\cline { 2 - 3 } & Laki-Laki & Perempuan & Y \\
\cline { 2 - 4 } & $\mathbf{X 1}$ & $\mathbf{X 2}$ & $1.790,431$ \\
\hline 2010 & 989,201 & 801,200 & $1.897,290$ \\
\hline 2012 & $1.002,145$ & 895,145 & $2.029,308$ \\
\hline 2015 & $1.021,188$ & $1.008,120$ & $2.072,421$ \\
\hline 2016 & $1.043,114$ & $1.029,407$ & $2.105,476$ \\
\hline 2017 & $1.058,234$ & $1.047,242$ & $9.894,926$ \\
\hline
\end{tabular}

\subsection{Algoritma Regresi Linear Berganda}

Uji coba dan analisa adalah untuk melihat bagaimana suatu proses pada software data mining, tujuan dari proses dan output yang diharapkan. Ujicoba ini bertujuan untuk melakukan perhitungan algoritma untuk mencari nilai prediksi terbaik yang akan menjadi pembagi terhadap atribut yang lainnya, dengan menggunakan perhitungan (rumus) regresi linear berganda. Regresi linear berganda akan dilatihkan terhadap pola data input dan target sebenarnya.

Regresi linier merupakan bentuk hubungan di mana variabel bebas X maupun variabel tergantung Y sebagai faktor yang berpangkat dua. Persamaan umum algoritma regresi linier berganda, adalah :

$\mathrm{Y}=a 0+a 1 . \mathrm{X} 1+a 2 . \mathrm{X} 2+\ldots+a \mathrm{n} . \mathrm{Xn}$

Keterangan :

$\mathrm{Y}=$ variabel terikat / variabel dependent (nilai yang diprediksi)

$a 0, a 1, a 2, a \mathrm{n}=$ koefisien regresi

$\mathrm{X} 1, \mathrm{X} 2, \ldots, \mathrm{Xn}=$ variabel bebas / variabel independent.

Analisis regresi linier berganda digunakan untuk mengestimasi pertumbuhan penduduk sebagai (Y) di BPS Kabupaten Deli Serdang ditinjau dari 2 variabel yaitu Jumlah Laki-Laki (X1) dan Jumlah Perempuan (sebagai X2) yang akan dilakukan prediksi menggunakan analisis regresi linier berganda. Untuk mencari 
nilai konstanta dan variable regresi setiap variabel bebas dapat diperoleh dengan menggunakan rumus regresi linear berganda.

Tabel.4 Learning Dataset

\begin{tabular}{|c|c|c|c|}
\hline \multirow{2}{*}{ Tahun } & \multicolumn{2}{|c|}{ Penduduk } & \multirow{2}{*}{ Jumlah Penduduk } \\
\cline { 2 - 4 } & Laki-Laki & Perempuan & Y \\
\cline { 2 - 4 } & $\mathbf{X 1}$ & $\mathbf{X 2}$ & $1.790,431$ \\
\hline 2010 & 989,201 & 801,200 & $1.897,290$ \\
\hline 2012 & $1.002,145$ & 895,145 & $2.029,308$ \\
\hline 2015 & $1.021,188$ & $1.008,120$ & $2.072,421$ \\
\hline 2016 & $1.043,114$ & $1.029,407$ & $2.105,476$ \\
\hline 2017 & $1.058,234$ & $1.047,242$ & $9.894,926$ \\
\hline
\end{tabular}

Kemudian memproses ikhtisar perhitungan berdasarkan nilai x1, x2 dan y pada Tabel.4 diatas. Sehingga hasilnya seperti terlihat dibawah ini.

Tabel.5 Ikhtisar Perhitungan

\begin{tabular}{|c|r|r|r|r|r|}
\hline Tahun & \multicolumn{1}{|c|}{ X1^2 } & \multicolumn{1}{c|}{ X1*X2 } & \multicolumn{1}{c|}{ X1*Y } & \multicolumn{1}{c|}{$\mathbf{X 2}^{\wedge} \mathbf{2}$} & \multicolumn{1}{c|}{ X2*Y } \\
\hline 2010 & 978.519 & 792.548 & 1.771 .096 & 641.921 & 1.434 .493 \\
\hline 2012 & 1.004 .295 & 897.065 & 1.901 .360 & 801.285 & 1.698 .350 \\
\hline 2015 & 1.042 .825 & 1.029 .480 & 2.072 .305 & 1.016 .306 & 2.045 .786 \\
\hline 2016 & 1.088 .087 & 1.073 .789 & 2.161 .771 & 1.059 .679 & 2.133 .365 \\
\hline 2017 & 1.119 .859 & 1.108 .227 & 2.228 .086 & 1.096 .716 & 2.204 .943 \\
\hline Jumlah & 5.233 .584 & 4.901 .109 & 10.134 .618 & 4.615 .907 & 9.516 .937 \\
\hline
\end{tabular}

Untuk memperkecil angka yang terdapat pada tabel diatas, maka dilakukan pembagian/10000 setiap data pada tabel diatas, sehingga hasilnya menjadi :

Tabel.6 Penyederhanaan Ikhtisar Perhitungan (dibagi 10000)

\begin{tabular}{|c|c|c|c|c|c|}
\hline Tahun & $X 1^{\wedge} 2$ & $\mathrm{X} 1 * \mathrm{X} 2$ & $\mathbf{X} 1 * \mathbf{Y}$ & $X 2^{\wedge} 2$ & $\mathbf{X} 2 * \mathbf{Y}$ \\
\hline 2010 & 97,852 & 79,254 & 177,110 & 64,192 & 143,449 \\
\hline 2012 & 100,429 & 89,706 & 190,135 & 80,128 & 169,834 \\
\hline 2015 & 104,282 & 102,948 & 207,230 & 101,631 & 204,579 \\
\hline 2016 & 108,809 & 107,379 & 216,177 & 105,968 & 213,336 \\
\hline 2017 & 111,986 & 110,823 & 222,809 & 109,671 & 220,494 \\
\hline Jumlah & 523,358 & 490,110 & 1013,461 & 461,591 & 951,694 \\
\hline
\end{tabular}

Untuk memperoleh koefisien regresi $a, b_{1}$ dan $b_{2}$ dapat diperoleh dengan cara simultan dari tiga persamaan sebagai berikut:

$a_{n}+b_{1} \Sigma \mathrm{X}_{1}+b_{2} \Sigma \mathrm{X}_{2}=\Sigma \mathrm{Y}$

(Persamaan 1)

$a \Sigma \mathrm{X}_{1}+b_{1} \Sigma \mathrm{X}_{1}^{2}+b_{2} \Sigma \mathrm{X}_{1} \mathrm{X}_{2}=\Sigma \mathrm{X}_{1} \mathrm{Y}$

(Persamaan 2)

$a \Sigma \mathrm{X}_{2}+b_{1} \Sigma \mathrm{X}_{1} \mathrm{X}_{2}+b_{2} \Sigma \mathrm{X}_{2}^{2}=\Sigma \mathrm{X}_{2} \mathrm{Y}$

(Persamaan 3)

Kemudian masukkan angka yang telah didapat pada ikhtisar perhitungan (Tabel.6) dan nilai $\Sigma \mathrm{X}_{1}, \Sigma \mathrm{X}_{2}$ dan $\Sigma Y$ (dari Tabel.4) sehingga diperoleh hasil persamaan 1, 2 dan 3.

$\mathrm{a} 5+\mathrm{b} 1(5113,882)+\mathrm{b} 2(4781,114)=9894,926 \ldots \ldots \ldots \ldots \ldots \ldots \ldots($ Persamaan 1$)$

$\mathrm{a}(5113,882)+\mathrm{b} 1(523,3584)+\mathrm{b} 2(490,1108)=1013,461 \ldots \ldots \ldots($ Persamaan 2$)$

$\mathrm{a}(4781,114)+\mathrm{b} 1(490,1108)+\mathrm{b} 2(461,591)=951,694 \ldots \ldots \ldots \ldots .($ Persamaan 3$)$ 
Kemudian ketiga persamaan diatas diselesaikan hingga memperoleh nilai pada a, b1, dan b2. Langkahlangkah penyelesaiannya adalah sebagai berikut :

1. Pertama, persamaan 1 dan 2 di eliminasi

\begin{tabular}{l|l}
$5 \mathrm{a}+\mathrm{b} 1(5113,882)+\mathrm{b} 2(4781,114)=9894,926$ & x 5113,882 \\
$(5113,882) \mathrm{a}+\mathrm{b} 1(523,3584)+\mathrm{b} 2(490,1108)=1013,461 \times 5$ &
\end{tabular}

$25569,41 \mathrm{a}+26151789 \mathrm{~b} 1+24450053 \mathrm{~b} 2=50601484$

$25569,41 \mathrm{a}+2616,792 \mathrm{~b} 1+2450,554$ b2 $=5067,3092$

26149172,32 b1 $+24447602,27$ b2 $=50596416,65$

(Persamaan 4)

2. Kemudian persamaan 1 dan 3 di eliminasi

$5 \mathrm{a}+\mathrm{b} 1(5113,882)+\mathrm{b} 2(4781,114)=9894,926$

x 4781,114

$(4781,114) a+b 1(490,1108)+b 2(461,591)=951,694$

$\mathrm{x} 5$

$23905,57 \mathrm{a}+24450053 \mathrm{~b} 1+22859051 \mathrm{~b} 2=47308769$

$23905,57 \mathrm{a}+2450,554 \mathrm{~b} 1+2307,953 \mathrm{~b} 2=4758,468$

$24447602,3 \mathrm{~b} 1+22856743,13 \mathrm{~b} 2=47304010,76$

3. Lalu persamaan 4 dan 5 di eliminasi

\begin{tabular}{ll|l}
26149172,32 b1 $+24447602,27$ b2 $=50596416,65$ & x 26149172,32 \\
24447602,3 b1 $+22856743,13$ b2 $=47304010,76$ & x 24447602,3
\end{tabular}

639284564518594 b1 + 597685256756465 b2 $=1236961070636660$

639284564518594 b1 + 597684914671743 b2 = 1236960728669810

342084722 b2 $=341966850$

b2 = $341966850: 342084722$

b2 $=0,9997$

4. Kemudian masukkan nilai b2 kedalam persamaan 4 dengan mensubsitusikan.

26149172,32 b1 + 24447602,27 b2 $=50596416,65$

26149172,32 b1 $+24447602,27 *(0,9997)=50596416,65$

26149172,32 b1 $+24439178,37=50596416,65$

26149172,32 b1 $=24439178,37+50596416,65$

26149172,32 b1 $=75035595,02$

b1 $=75035595,02: 26149172,32$

b1 $=\mathbf{2 , 8 6 9 5}$

5. Kelima, masukkan nilai b1 dan b2 ke persamaan 1 dengan mensubsitusikan.

$5 \mathrm{a}+\mathrm{b} 1(5113,882)+\mathrm{b} 2(4781,114)=9894,926$

$5 \mathrm{a}+(2,8695 * 5113,882)+(0,9997 * 4781,114)=9894,926$

$5 a+14674,391+4779,467=9894,926$

$5 a+19453,858=9894,926$

$5 \mathrm{a}=9894,926-19453,858$

$5 \mathrm{a}=-9558,932$

$a=-9558,932: 5$

$\mathrm{a}=\mathbf{- 1 9 1 1 , 7 8 6}$

Jadi sekarang telah didapat nilai a, b1, b2 dimana nilai-nilainya adalah sebagai berikut :

$\mathrm{a}=-1911,786$

b1 $=2,8695$

b2 $=0,9997$

Sehingga menghasilkan persamaan regresi sebagai berikut :

$Y=-1911,786+2,8695 X_{1}+0,9997 X_{2}$

Setelah persamaan regresi linear didapatkan, maka untuk mengestimasi pertumbuhan penduduk dapat diperoleh dengan mudah. Dengan memasukkan nilai x1 dan x2 pada periode tahun terakhir (tahun 2017) yaitu nilai x1 sebesar 1.058,234 dan nilai x2 sebesar 1.047,242. Maka menghitung mengestimasi pertumbuhan penduduk adalah dengan menggunakan persamaan regresi linear berganda diatas, sehingga:

$\mathrm{Y}=a+b 1 . \mathrm{x} 1+b 2 . \mathrm{x} 2$

$=-1911,786+2,8695 \mathrm{X}_{1}+0,9997 \mathrm{X}_{2}$

$=-1911,786+(2,8695 * 1.058,234)+(0,9997 * 1.047,242)$

$=2171,7194$ dikali 1.000

= 2.171.719 Penduduk

Maka hasil dari estimasi (perkiraan) pertumbuhan penduduk pada Kabupaten Deli Serdang pada periode tahun 2018 adalah sebanyak 2.171.719 jiwa. Terjadi penambahan penduduk sebanyak 66.243 jiwa dibanding tahun 2017. 


\section{KESIMPULAN}

Analisa dan pembahasan data mining dengan teknik estimasi menggunakan metode Regresi Linear Bergandayang dilakukan di Badan Pusat Statistik Kabupaten Deli Serdang tentang prediksi laju pertumbuhan penduduk, maka dapat ditarik kesimpulan bahwa sebagai berikut:

1. Hasil dari analisa yang diperoleh dari data mining dengan metode Regresi Linear Berganda mengenai prediksi laju pertumbuhan penduduk dapat membantu pihak Badan Pusat Statistik Kabupaten Deli Serdang mengetahui atribut/kriteria apa saja yang mempengaruhi laju pertumbuhan penduduk. Dan juga ditemukan pola yang saling berkaitan erat antara atribut jumlah laki-laki dan jumlah perempuanterhadap laju pertumbuhan penduduk.

2. Dalam merancang system dilakukan dengan cara melakukan proses perhitungan Regresi Linier Berganda kemudian menghitung persamaan dan kemudian hasil estimasi regresi.

3. Sistem ini dapat diimplementasikan untuk mengestimasi laju pertumbuhan penduduk menggunakan metode Regresi Linier Berganda dengan hasil yang cukup akurat.

\section{REFERENSI}

[1] Saharia Samsu (2013). Analisis Pengakuan Dan Pengukuran Pendapatan Berdasarkan Psak No. 23 Pada Pt. Misa Utara Manado. Jurnal EMBA, 1(3),571.

[2] Muhammad Syahrizal (2012). Perancangan Sistem Aplikasi Pembuatan Roster Mata Kuliah Pada Perguruan Tinggi. Jurnal Pelita Informatika Budi Darma, 1(3),38.

[3] Harris Kurniawan, et.al (2014). Analisa Pola Data Penyakit Rumah Sakit Dengan Menerapkan Metode Association Rule Menggunakan Algoritma Apriori. Jurnal Seminar Nasional Informatika, 196.

[4] Febri Nova Lenti (2014). Rekayasa Database Terdistribusi Pada Layanan Pemesanan Tiket Pesawat Terbang. Jurnal Teknologi Technoscienta, 6(2),130.

[5] Ali Fikri (2009). Penerapan Data Mining Untuk Mengetahui Tingkat Kekuatan Beton Yang Dihasilkan Dengan Metode Estimasi Menggunakan Linear Regression. 